\title{
Analysis of the Effect of Motivation and Training on the Performance of Nurses in Datu Beru Takengon Public Hospital
}

\author{
Vina Rezeki', Arifah Devi Fitriani', Iman Muhammad ${ }^{1}$, Lucia Lastiur ${ }^{1}$ \\ ${ }^{1}$ Helvetia Health Institute Medan, Indonesia \\ Corresponding Author: Vina Rezekis
}

Email:vinapasarela123@gmail.com

\section{Article Info \\ Article history: \\ Received 9 October 2020 \\ Received in revised form 17 \\ October 2020 \\ Accepted 19 October 2020}

\section{Keywords:}

Motivation

Training

Nurse Performance

\author{
Abstract
}

Nurses who work in emergency room must have more skills, which is implied for every nurse who works in the emergency room to have a good performance. The study aims to analyze the influence of motivation and training on the performance of nurses in the emergency room at Datu Beru Takengon General Hospital in 2018.The design used a quantitative analytic survey. The population were all nurses in the emergency room of Datu Beru Hospital in Takengon by totalling 32 nurses and all were taken as the sample by using total population technique. Data analysis was performed by univariate, bivariate and multivariate analyses.The results showed that out of 15 respondents who had less motivation had a poor performance in the category of less than 9 people $(60 \%)$ and of the 17 respondents who were motivated, motivation with nurse performance with Chi-Square statistical test obtained p-value $=.032<\alpha$ .05 , which means that there is an influence between training and nurse performance $.001<\alpha .05$, which means there is an influence between training and nurse performance.The conclusion is that there is an influence between motivation and training on the performance of nurses in the emergency room. It is recommended that the hospital management pay attention to the performance of the nurses, by giving riward to nurses who have good performance and giving sanctions to nurses who break the rules.

\section{Introduction}

The performance of nurses is an important aspect in the hospital, because this is what will determine the progress or withdrawal of the hospital. Nurses are an integral part of the hospital. Those who treat patients are not only given physical assistance but also from a psychological aspect (Vande Berg, 2017). According to the World Health Organization (WHO), performance is a world issue today. The results of research by the Directorate of Nursing and PPNI regarding nursing activities show that more than $75 \%$ of all health service activities are nursing service activities (Wahyuni \& Arruum, 2011). Common problems that have occurred in nursing services to date are the lack of nurses who have higher education, the number of nurses who are less friendly and the lack of patience of nurses in dealing with patients (Wahyuni \& Arruum, 2011; Allo et al., 2020).

Motivation according to Maslow's theory of needs in Marquis and Huston consists of physiological needs, security, ownership, self-esteem and self-actualization. Maslow's theory is the theory most often used by practitioner managers because it is logical and intuitively explained (Maslow, 2010). IGD nurses are required to equip themselves with knowledge, 
skills, and even take part in trainings that can help nurses handle patients quickly and accurately (Kurnianingsih, Suroso, \& Muhajirin, 2013; Amirah, 2019).

Based on data from the workforce taken in 2018 at the Datu Beru Takengon Regional Hospital, the number of nurses working in the emergency room was 32 people, consisting of 12 nurses with 12 undergraduate nursing graduates, 18 D-III Nursing people and 2 Nursing DIV person. From the condition of the number of nurses, the nurses work divided based on shifts, namely: morning, evening and night. So the number of nurses working in one shift, namely the night shift, is only 7 people, while the number of services and assistance for emergency cases in the ER is increasing.

Based on the data that the researchers got at the Datu Beru Hospital, there were 32 IGD nurses and supported by data obtained from the emergency attendance records at Datu Beru Hospital in April-June 2018, there were still many nurses who did not comply with the arrival and return hours of work accordingly. applicable regulations, such as not using uniforms or service attributes in accordance with hospital regulations, there are also nurses who are still negligent with attendance.

Based on data on delays and early discharge from emergency room nurses at Datu Beru Hospital, it can be seen that from April to June there was an increase in tardiness for 1 nurse more than 7 times per month, in April as much as 8.33\%, in May as much as $27.1 \%$ and in June as much as $41.6 \%$. Meanwhile, the data for nurses who left early also increased more than 5 times each month, namely in April as much as 4.12\%, in May as much as $12.5 \%$ and in June as much as $22.92 \%$. From the results of observations and interviews, researchers with nursing and staffing committee staff, they said that some nurses still seemed not to comply with regulations related to discipline, such as not using uniforms or service attributes in accordance with hospital regulations, there were also nurses who were still negligent of attendance with excuses for forgetting and other reasons.

Based on the initial survey, there were still nurses who made mistakes in implementing nursing care in the emergency room at Datu Beru Takengon Hospital, such as: incomplete filling of client nursing assessment sheets, delays in handling when there were patients who were emergency due to waiting for instructions from doctors and there were still nurses who were not yet skilled in handling cases of emergency patients, after being assessed it turned out that the nurse had never attended any training. If the training and motivation are not carried out properly, Datu Beru Hospital will find it difficult to survive and win the competition in producing satisfying services for patients. But the reality is that what happens to nurses at Datu Beru Takengon General Hospital is the lack of motivation of nurses towards performance, because the rewards given do not match their performance (Achadi et al., 2010). The research objective was to analyze the influence of motivation and training on the performance of nurses in the emergency room at Datu Beru Takengon General Hospital.

\section{Methods}

This type of quantitative analytic survey research with a cross-sectional design is to analyze the effect of motivation and training on the performance of nurses in the emergency room of the Datu Beru Takengon General Hospital and was carried out in April 2018 to January 2019. The population was 32 nurses and a sample of 32 nurses with total sampling technique. The variables studied were intrinsic and extrinsic training and motivation. The tools for data collection were questionnaires and nurse performance observation sheets. The data that has been collected is processed by univariate, bivariate and multivariate analysis and statistical analysis is used with the Statistical Package for The Social Science (SPSS). 


\section{Results and Discussion}

Table 1 shows that out of 32 respondents aged $<25$ years were 8 people (32\%), respondents aged 26-36 years were 14 people (42\%) and respondents aged $>36$ years were 10 people $(32 \%)$, and Respondents with S2 education were $2(21 \%), 12$ respondents $(63.3 \%)$ with S1 education, while 18 people with D-III education $(10.5 \%)$.

Table 1. Distribution of Nurse Characteristics

\begin{tabular}{|l|c|c|}
\hline \multicolumn{1}{|c|}{ Characteristics } & N & Percentage \\
\hline Age & & \\
<25 Years & 8 & 25 \\
26-36 Years & 14 & 44 \\
>36 Yearss & 10 & 31 \\
Education & & \\
Master Degree & 2 & 6 \\
Bachelor Degree & 12 & 38 \\
Diploma & 18 & 56 \\
\hline \multicolumn{1}{|c|}{ Total } & 32 & 100 \\
\hline
\end{tabular}

Table 2 shows that of the 15 respondents who had less motivation had a poor performance as many as 9 people $(60 \%)$ and of the 17 respondents who had good motivation dominantly had good performance too, namely 17 people $(100 \%)$ and the p-value. $=0.001<\alpha 0.05$, there is a relationship between motivation and nurse performance. From the results, 21 respondents who did not attend the training had good performance as many as 12 people (57\%) and of the 11 respondents who had attended the training also had good performance, namely 11 people $(100 \%)$ and $p$-value $=0.032<\alpha 0,05$, which means that there is a relationship between training and nurse performance.

Table 2.The Relationship between Motivation and Training and Performance of Nurses in the Emergency Room (IGD) Datu Beru Takengon Hospital

\begin{tabular}{|c|c|c|c|c|c|c|}
\hline \multirow{3}{*}{ Variabel } & \multicolumn{4}{|c|}{ Kinerja Perawat } & \multirow{3}{*}{ Amount } & \multirow{3}{*}{$\mathbf{p}$} \\
\hline & \multicolumn{2}{|r|}{ Less } & \multicolumn{2}{|c|}{ Good } & & \\
\hline & $\mathbf{n}$ & Percentage & $\mathbf{n}$ & Percentage & & \\
\hline Motivation & & & & & & \\
\hline Less & 9 & 60 & 6 & 40 & 15 & 0,001 \\
\hline Good & 0 & 0 & 17 & 100 & 17 & \\
\hline Training & & & & & & \\
\hline Available & 9 & 43 & 12 & 57 & 21 & 0,032 \\
\hline Not Availables & 0 & 0 & 11 & 100 & 11 & \\
\hline Total & 9 & & 23 & & 32 & \\
\hline
\end{tabular}

Table 3 shows that for the motivation variable the Sig value is obtained. $0.001<$ from p: 0.05 ; means that there is a significant influence of the motivation variable on the nurse's performance and for the training variable the Sig value is obtained. $0.011<$ from p: 0.05 ; means that there is a significant influence of the training variable on the nurse's performance.

Table 3. The Effect of Motivation and Training on the Performance of Nurses in the Emergency Room of the Datu Beru Takengon Hospital 


\begin{tabular}{|c|c|c|c|c|c|c|}
\hline \multicolumn{7}{|c|}{ Coefficients $^{\mathrm{a}}$} \\
\hline & & \multicolumn{2}{|c|}{$\begin{array}{c}\text { Unstandardized } \\
\text { Coefficients }\end{array}$} & \multirow{2}{*}{$\begin{array}{c}\begin{array}{c}\text { Standardized } \\
\text { Coefficients }\end{array} \\
\text { Beta } \\
\end{array}$} & \multirow[b]{2}{*}{$\mathrm{t}$} & \multirow[b]{2}{*}{ Sig. } \\
\hline \multicolumn{2}{|c|}{ Model } & $\mathrm{B}$ & Std. Error & & & \\
\hline \multirow[t]{3}{*}{1} & (Constant) & .992 & 1.896 & & .523 & .605 \\
\hline & Motivation & .379 & .113 & .478 & 3.358 & .002 \\
\hline & Training & .203 & .075 & .388 & 2.724 & .011 \\
\hline
\end{tabular}

Motivation is a condition within a person that encourages the individual's desire to carry out certain activities, in order to achieve a goal (Arifin et al., 2013; Achadi et al., 2010; Zulaekah $\&$ Widajanti, 2010). Motivation for good nurses is because motivation is the main key that determines the performance of nurses because in providing nursing care where nurses must have a strong drive and willingness to implement it according to the stages and standards that have been set.

This is also in accordance with the theory where in order to optimize the quality of performance and health services, efforts to increase work motivation, namely by giving awards to those who have more abilities, creating a conducive environment, establishing good relationships with colleagues, providing job security, establish good relationships between superiors and subordinates, participate in seminars and trainings (Aryandini, 2015).

The results of interview data through the observation that motivation is the main key that determines the performance of nurses because in carrying out nursing care where nurses must have a strong drive and willingness to carry it out according to the stages and standards that have been set. Even though the abilities, attitudes, facilities and leadership are good and the rewards given are satisfactory, if the nurse does not have the motivation to carry out the nursing care documentation that has been implemented, then the performance in providing services to patients will not be achieved and will not result in good performance. This is evident from the results of the study that nurses with high motivation have better performance than nurses with low motivation and their performance results are also not good.

Training is a form of worker enrichment and empowerment. Job enrichment expands work by improving conditions by means of work planning, implementation and evaluation controlled by workers (Savall, 2010; Tandirerung et al., 2013). The result of effective training is to increase the skills, knowledge, and attitudes of these employees. Quality skills, knowledge, and attitudes are several indicators of the success of the training conducted (Hapsari, 2013). Training and development are terms related to planning efforts, to achieve mastery of skills, knowledge and attitudes of employees or organizational members (Achadi et al., 2010).

In providing services, training and motivation are interrelated with one another, because both play an important role in the performance of a nurse in the hospital, but if nurses have training without motivation, it is the same as nurses who do not know their duties (Emilia, 2009; Lambrou et al., 2010).

The results of statistical analysis obtained $p$-value $=0.032<\alpha 0.05$, which means that there is a relationship between training and nurse performance. This is because nurses who actively participate in training have knowledge and skills and good performance in providing services, nurses are more responsible and easier when providing services to patients, on the other hand nurses who rarely attend training have poor performance because of new knowledge given during the training will not be obtained while the reality in the field of nursing science continues to develop in accordance with the knowledge and technology which in turn will have a separate impact on the skills acquired by nurses (Larson \& Story, 2010). 
The skills they have will also decrease because they do not participate in training, where the current training is not only in the form of theory but also in the form of practitioners which must be mastered by participants who take part in the training so that when providing services to patients cannot be done properly (Larson \& Story, 2010). The results of this study are in line with previous research, namely Juliati's (2015) study entitled The Relationship of Training to the Performance of Nurses at the Pangkalan Brandan Pertamedika Hospital. The results of the relationship between training and the performance of nurses at Pertamina Pangkalan Brandan General Hospital were obtained (Juliati, 2015). This result is in line with the research of Aulia et al. (2014), who found that training had a significant effect on the performance of inpatient nurses at the Siak District Hospital. This is also reinforced by Lumbanraja's (2010) research, which proves that there are differences in the work performance of nurses before and after participating in training at the Langsa Regional General Hospital Health Service Agency (Juliati, 2015). Training that has been followed by nurses can improve work performance, as well as research conducted by Dai (2008) on the relationship between training on nurse performance, states that there is a significant relationship between training and performance with the interpretation that the training provided greatly adds to knowledge so that it can improve the performance. This proves that training has an effect on one's performance (Juliati, 2015).

Motivation and training are factors that can generally affect performance. Training and motivation are two factors that are interrelated with one another, because both play an important role in the performance of a nurse in the hospital, but if the nurse has training without motivation, it is the same as a nurse who does not know her job. Likewise, if the nurse has motivation but never participates in training, this will make the nurse not develop in his knowledge, while the patient's demands are always about quality service quality. Training is one of the efforts to improve the quality of Human Resources in an organization. By increasing the quality of human resources in the organization, it will improve the performance of nurses in providing services to patients (Shyddiq, 2014).

The results of this study are in line with previous research, namely research entitled Analysis of the Influence of Motivation, Job Training and Compensation on Nurse Performance in the Majenang Regional General Hospital (RSUD) where the results of the study can be concluded that collectively the independent variables have an influence on the performance of nurses, namely with motivation $(\mathrm{X} 1)=78.2 \%$, Job Training $(\mathrm{X} 2)=72.9 \%$, and Compensation $(\mathrm{X} 3)=$ $76.1 \%$ have a significant and stimulating effect on nurse performance $(Y)=72.7 \%$. This means that increased motivation, job training, and compensation will improve the performance of nurses at the Regional General Hospital (RSUD) Majenang. Of the three independent variables, the motivation variable has the most significant effect $78.2 \%$ on the performance of nurses.

The results of interview data through observation that work motivation is important for nurses, especially benefits for nurses and hospitals. Motivation will encourage nurses to be more accomplished and productive. Likewise motivation at the hospital in order to improve service and comfort through improving employee attitudes and behavior, it is necessary to increase the attention of the hospital so that the services provided by nurses have increased both in terms of quality and quality, the hospital must be able to motivate nurses properly and provide Maximum job training so that nurses in the hospital, especially the IGD, are more enthusiastic in working so that the quality and quality of their services can increase and the compensation for nurses also increases.

\section{Conclusion}


There is a relationship between motivation and training with the performance of nurses in the Emergency Room of the Datu Beru Takengon General Hospital in 2018.It is recommended that the hospital pay more attention to the work motivation of nurses who are described by responsibilities, working conditions, supervision and incentives and by providing regular seminars and continuously and improve the work environment for nurses and create a comfortable and safe atmosphere for nurses and provide training in the field of nursing.

\section{Thank-You-Note}

The researcher would like to thank the enumerators who gave a lot of help and support as well as thanks to the Director and all room staff in the ER at Datu Beru Takengon General Hospital who had given permission as a place to carry out research.

\section{References}

Achadi, E., Arifah, S., Muslimatun, S., Anggondowati, T., \& Setiarini, A. (2010). Efektivitas Program Fortifikasi Minyak Goreng dengan Vitamin A terhadap Status Gizi Anak Sekolah di Kota Makasar. Kesmas: National Public Health Journal, 4(6), 255-261.

Achadi, E., Pujonarti, S. A., Sudiarti, T., Rahmawati, R., Kusharisupeni, K., Mardatillah, M., \& Putra, W. K. Y. (2010). Sekolah dasar pintu masuk perbaikan pengetahuan, sikap, dan perilaku gizi seimbang masyarakat. Kesmas: National Public Health Journal, $5(1), 42-48$.

Allo, A. A., Muis, M., Ansariadi, A., Wahyu, A., Russeng, S. S., \& Stang, S. (2020). Work Fatigue Determination of Nurses in Hospital of Hasanuddin University. Journal of Asian Multicultural Research for Medical and Health Science Study, 1(2), 33-41.

Amirah, A. (2019). Implementation of Surveillance System Based on Characteristics and Health Status of Hajj Pilgrims Candidates of Banda Aceh (BTJ) in 2019. IJOInternational Journal of Health Sciences and Nursing, 2(09), 01-10.

Arifin, S. U., Mayulu, N., \& Rottie, J. (2013). Hubungan asupan zat gizi dengan kejadian anemia pada anak sekolah dasar di kabupaten Bolaang Mongondow Utara. Jurnal Keperawatan, 1(1).

Aryandini, E. (2015). Hubungan Motivasi Kerja Dengan Tingkat Kinerja Perawat di Unit Kegawatdaduratan Rumah Sakit PKU Muhammadiyah Yogyakarta. Keperawatan (eKp), 1-16.

Emilia, E. (2009). Pendidikan gizi sebagai salah satu sarana perubahan perilaku gizi pada. Jurnal Tabularasa, 6(2), 161-174.

Hapsari, R. N. (2013). Kontribusi Makanan Jajanan terhadap tingkat Kecukupan Asupan Energi dan Protein Pada Anak Sekolah yang Mendapat PMT-AS Di SD Negeri Plalan 1 Kota Surakarta. Thesis, Universitas Muhammadiyah Surakarta.

Juliati. (2015). Hubungan Pelatihan Terhadap Kinerja Perawat Pelaksana Di Rumah Sakit Pertamedika Pangkalan Brandan. Jurkessutra, 2(5), 1-13.

Kurnianingsih, D., Suroso, J., \& Muhajirin, A. (2013). Efektifitas Terapi Musik Klasik Terhadap Penurunan Stres Kerja Perawat IGD Di RSUD Dr . R . Goetheng Taroenadibrata Purbalingga Tahun 2013. Prosiding Konferensi Nasional, 166-172.

Lambrou, P., Kontodimopoulos, N., \& Niakas, D. (2010). Motivation and job satisfaction among medical and nursing staff in a Cyprus public general hospital. Human resources for health, 8(1), 26. 
Larson, N., \& Story, M. (2010). Are 'competitive foods' sold at school making our children fat? Health Affairs, 29(3), 430-435.

Maslow, A. H. (2010). Motivation and Personality. Jakarta: Rajawali.

Savall, H. (2010). Work and people: An economic evaluation of job enrichment. IAP.

Shyddiq, N. F. (2014). Pengaruh Pelatihan Terhadap Kinerja Perawat Pada Instalasi Gawat Darurat RSUP Dr. Hasan Sadikin Bandung, 18.

Tandirerung, E. U., Mayulu, N., \& Kawengian, S. E. S. (2013). Hubungan Kebiasaan Makan Pagi dengan Kejadian Anemia pada Murid Sd Negeri 3 Manado. Jurnal E-Biomedik, 1(1).

Vande Berg, B. J. . (2017). Pengaruh Kompetensi Dan Motivasi Terhadap Kinerja Perawat Pada Rumah Sakit PTPN VIII Subang. Journal of Biological Chemistry, 276(5), 3408-3416.

Wahyuni, I., \& Arruum, D. (2011). Motivasi dan kinerja perawat pelaksana di rumah sakit bhayangkara medan. Thesis, Universitas Sumatera Utara.

Zulaekah, S., \& Widajanti, L. (2010). Pengetahuan gizi dan kadar hemoglobin anak sekolah dasar penderita anemia setelah mendapatkan suplementasi besi dan pendidikan gizi. Kesmas: National Public Health Journal, 5(1), 36-41. 